\title{
Cesiribacter roseus sp. nov., a pink-pigmented bacterium isolated from desert sand
}

\author{
Ming Liu, ${ }^{1}$ Huan Qi, ${ }^{1}$ Xuesong Luo, ${ }^{2}$ Jun Dai, ${ }^{1}$ Fang Peng ${ }^{1}$ \\ and Chengxiang Fang ${ }^{1}$ \\ ${ }^{1}$ College of Life Sciences, Wuhan University, Wuhan 430072, PR China \\ ${ }^{2}$ School of Environmental Studies, China University of Geosciences, Wuhan 430074, PR China
}

Correspondence

Fang Peng

fangpeng2@yahoo.com.cn

Chengxiang Fang

cxfang@whu.edu.cn
The genus Cesiribacter was proposed by Srinivas et al. (2011) based on the description of a Gram-negative, nonmotile, aerobic bacterium with high DNA G $+\mathrm{C}$ content. The genus was related phylogenetically to the genus Marivirga of the family Flammeovirgaceae. At the time of writing, the genus comprises one recognized species, Cesiribacter andamanensis.

The family Flammeovirgaceae includes several genera, including Aureibacter, Cesiribacter (Srinivas et al., 2011), Flammeovirga, Flexithrix, Limibacter, Marinoscillum (Seo et al., 2009), Marivirga (Nedashkovskaya et al., 2010), Perexilibacter, Persicobacter, Roseivirga (Nedashkovskaya et al., 2005a; Lau et al., 2006), Rapidithrix, Sediminitomix and Thermonema, and was described by Yoon et al. (2011). During investigation of the microbial diversity of desiccated environments of the Taklimakan desert of Xinjiang, China, numerous bacteria were isolated, including a pinkpigmented bacterial strain, designated $311^{\mathrm{T}}$, isolated from a sand sample. For isolation, $1 \mathrm{~g}$ aliquots of sand were serially diluted in saline water $(0.85 \%, \mathrm{w} / \mathrm{v})$ and plated onto tenfold-diluted trypticase soy agar $(0.1 \times$ TSA; Difco). After incubation at $30{ }^{\circ} \mathrm{C}$ for 20 days, single colonies on the plates were purified. Strain $311^{\mathrm{T}}$ was stored by lyophilization.

Genomic DNA extraction and amplification of the $16 \mathrm{~S}$ rRNA gene of strain $311^{\mathrm{T}}$ were carried out as described by Rainey et al. (1996). PCR products were sequenced by Invitrogen Biotechnology. Similarity searches with the

The GenBank/EMBL/DDBJ accession number for the 16S rRNA gene sequence of strain $311^{\top}$ is $\mathrm{HM} 775387$. derived sequences were performed via the EzTaxon server (Chun et al., 2007). Phylogenetic analysis was performed by using MEGA version 3.1 (Kumar et al., 2004) after multiple alignment of the data via CLUSTAL $\mathrm{x}$ (Thompson et al., 1997). Distances were obtained by using options according to Kimura's two-parameter model (Kimura, 1980) and clustering was performed by using the neighbour-joining method (Saitou \& Nei, 1987). The topology of the phylogenetic trees created with the neighbourjoining method was evaluated by using bootstrap resampling (Felsenstein, 1985) with 1000 replications (Fig. 1).

Cell morphology was examined by phase-contrast microscopy (Olympus) and by transmission electron microscopy. A number of key characteristics were also tested by using standard procedures (Gerhardt et al., 1994): $\mathrm{KOH}$ string test (Gram stain) and oxidase and catalase (3\% $\mathrm{H}_{2} \mathrm{O}_{2}$ ). Nitrate reduction and hydrolysis of aesculin, casein, starch and gelatin were tested according to Gerhardt et al. (1994). Flexirubin-type pigments were detected by using the simple $\mathrm{KOH}$ test detailed in the minimal standards for describing novel taxa in the family Flavobacteriaceae (Bernardet et al., 2002). Growth at 4, 12, $18,25,30,37,42$ and $45^{\circ} \mathrm{C}$ and with $0,1.0,2.0,3.0$ and $4.0 \% \mathrm{NaCl}$ was tested in tenfold-diluted trypticase soy broth $(0.1 \times \mathrm{TSB})$; growth at $\mathrm{pH} 6-11$ (intervals of $1 \mathrm{pH}$ unit) was determined in $0.1 \times$ TSB with $1 \% \mathrm{NaCl}$. Anaerobic growth was assessed on $0.1 \times$ TSA (both with and without $\mathrm{KNO}_{3}$ ) incubated in air-tight jars containing an AnaeroPack (Oxoid). Antibiotic resistance was determined with the disc diffusion method (Buczolits et al., 2002) on $0.1 \times$ TSA incubated for up to 3 days at $30{ }^{\circ} \mathrm{C}$. 


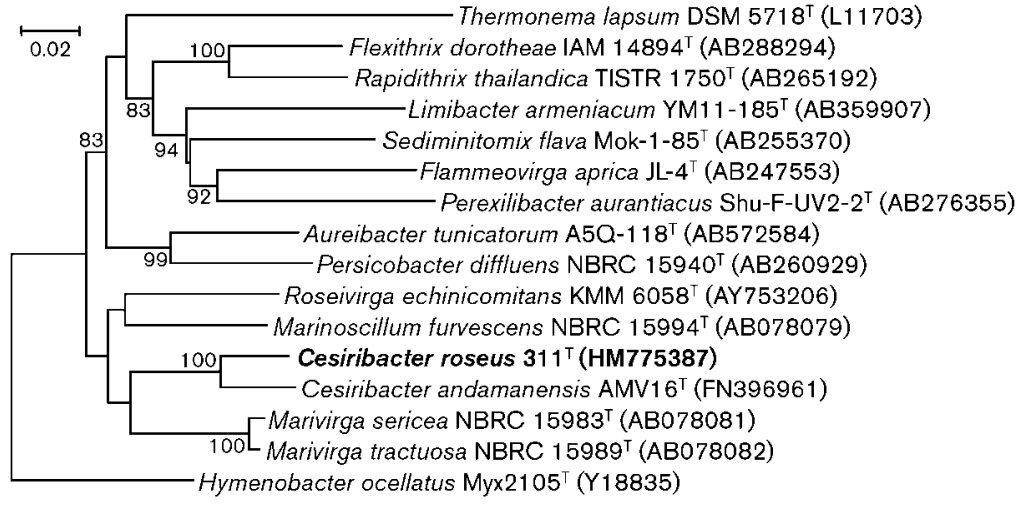

Fig. 1. Neighbour-joining tree based on $16 \mathrm{~S}$ rRNA gene sequences showing the phylogenetic relationship between strain $311^{\top}$ and related taxa. Bootstrap values (expressed as percentages of 1000 replications) $>70 \%$ are shown at nodes. Escherichia coli ATCC $11775^{\top}$ was used as an outgroup (not shown). Bar, 0.02 changes per nucleotide position.
Strain $311^{\mathrm{T}}$ was also characterized by using the whole test spectrum of the API ZYM, API 20NE and API 20E identification systems (bioMérieux) according to the manufacturer's instructions.

To determine its whole-cell fatty acid profile, strain $311^{\mathrm{T}}$ was grown on $0.1 \times$ TSA (Difco) with $1 \% \mathrm{NaCl}$ at $30{ }^{\circ} \mathrm{C}$ for 4 days, and analysis of the fatty acid methyl esters was carried out according to the standard protocol of the Sherlock Microbial Identification System (MIDI). Respiratory quinones were analysed according to the protocol of Xie \& Yokota (2003). DNA was extracted from cells grown in $0.1 \times$ TSB by using a modification of the protocol of Wilson (1987). The HPLC method of Mesbah et al. (1989) was used to determine the $\mathrm{G}+\mathrm{C}$ content of the extracted DNA.

16S rRNA gene sequence comparisons indicated that strain $311^{\mathrm{T}}$ was related phylogenetically to members of the genera Cesiribacter and Marivirga (Fig. 1). The phylogenetic tree showed that strain $311^{\mathrm{T}}$ formed a separate cluster with C. andamanensis $\mathrm{AMV} 16^{\mathrm{T}}$. Sequence comparisons also revealed that strain $311^{\mathrm{T}}$ exhibited highest $16 \mathrm{~S}$ rRNA gene sequence similarity $(94.6 \%)$ to $C$. andamanensis AMV16 ${ }^{\mathrm{T}}$ and showed relatively low levels of sequence similarity $(<90.0 \%)$ with respect to the type strains of other species.

Cells of strain $311^{\mathrm{T}}$ were strictly aerobic, Gram-negative, flexirubin-positive, variably shaped rods with an extracellular matrix (Fig. 2). Colonies were pink, circular and convex with regular margins after growth on $0.1 \times$ TSA at $30{ }^{\circ} \mathrm{C}$ for 3 days. Growth was observed at $4-37{ }^{\circ} \mathrm{C}$, with good growth at $30{ }^{\circ} \mathrm{C}$, at $0-3.0 \% \mathrm{NaCl}$ (optimum $2.0 \%$ ) and at $\mathrm{pH}$ 7-10 (optimum $\mathrm{pH}$ 8). Aesculin, gelatin, casein and starch were hydrolysed. Strain $311^{\mathrm{T}}$ was catalase- and nitrate reductase-positive, but oxidase-negative. The results of API ZYM, API 20E, API 20NE and antibiotic susceptibility tests are listed in the species description.

Based on chemotaxonomic characteristics, strain $311^{\mathrm{T}}$ could be easily differentiated from $C$. andamanensis AMV16 ${ }^{\mathrm{T}}$ and Marivirga tractuosa NBRC $15989^{\mathrm{T}}$. The major cellular fatty acids of strain $311^{\mathrm{T}}$ were $\mathrm{C}_{16: 1} \omega 5 \mathrm{c}$ $(29.9 \%)$, iso- $\mathrm{C}_{15: 0}(21.9 \%)$, iso- $\mathrm{C}_{17: 0} 3-\mathrm{OH}(13.3 \%)$ and summed feature 4 (iso- $\mathrm{C}_{17: 1} \mathrm{I}$ and/or anteiso- $\mathrm{C}_{17: 1} \mathrm{~B}$;
$13.0 \%$ ). In comparison, these components are present at low levels in C. andamanensis AMV16 ${ }^{\mathrm{T}}$ (Table 1). This fatty acid profile for $C$. andamanensis is highly atypical for members of the Bacteroidetes. Moreover, the DNA G+C content of strain $311^{\mathrm{T}}$ was $47.1 \mathrm{~mol} \%$ (HPLC), which is much higher than for the genus Marivirga (36-37 mol\%) (Table 2) but similar to that for C. andamanensis AMV16 ${ }^{\mathrm{T}}$.

The phenotypic, chemotaxonomic and phylogenetic data presented indicate that strain $311^{\mathrm{T}}$ represents a novel species of the genus Cesiribacter, for which the name Cesiribacter roseus sp. nov. is proposed.
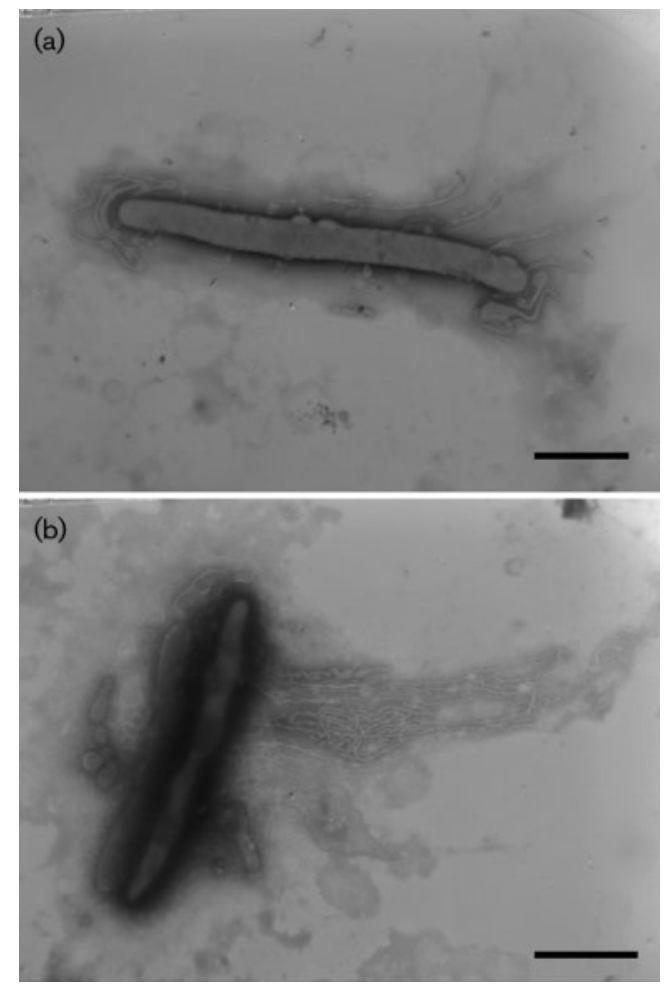

Fig. 2. Transmission electron micrographs of cells of strain $311^{\top}$ grown on R2A agar at $30{ }^{\circ} \mathrm{C}$ for $60 \mathrm{~h}(\mathrm{a})$ and on $0.1 \times \mathrm{TSA}$ at $30{ }^{\circ} \mathrm{C}$ for $60 \mathrm{~h}(\mathrm{~b})$. Bars, $700 \mathrm{~nm}(\mathrm{a})$ and $1 \mu \mathrm{m}(\mathrm{b})$. 
Table 1. Cellular fatty acid contents of strain $311^{\top}$ and the type strains of phylogenetically related species

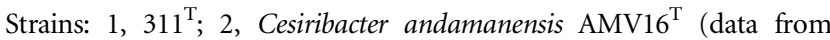
Srinivas et al., 2011); 3, Marivirga tractuosa NBRC $15989^{\mathrm{T}}$ [data from this study after growth on $0.1 \times$ TSA (Difco) with $1 \% \mathrm{NaCl}$ at $30{ }^{\circ} \mathrm{C}$ for 4 days]; 4, Roseivirga echinicomitans KMM $6058^{\mathrm{T}}$ (Nedashkovskaya et al., 2005b); 5, Marinoscillum furvescens DSM $4134^{\mathrm{T}}$ (Seo et al., 2009). ND, Not detected; tr, $<1 \%$.

\begin{tabular}{|c|c|c|c|c|c|}
\hline Fatty acid & 1 & $2^{*}$ & 3 & 4 & 5 \\
\hline $\mathrm{C}_{16: 1} \omega 5 c$ & 29.9 & $\mathrm{ND}$ & ND & ND & 28.5 \\
\hline iso- $\mathrm{C}_{15: 0}$ & 21.9 & 3.4 & 44.7 & 20.2 & 8.5 \\
\hline iso- $\mathrm{C}_{17: 0} 3-\mathrm{OH}$ & 13.3 & ND & 10.6 & 12.1 & 9.8 \\
\hline iso- $\mathrm{C}_{15: 1}$ & 4.0 & ND & $\operatorname{tr}$ & 20.2 & 3.2 \\
\hline $\mathrm{C}_{18: 0}$ & 3.7 & ND & $\mathrm{ND}$ & $\mathrm{ND}$ & ND \\
\hline iso- $\mathrm{C}_{17: 0}$ & 3.2 & ND & $\operatorname{tr}$ & 1.0 & 1.0 \\
\hline iso- $\mathrm{C}_{15: 0} 3-\mathrm{OH}$ & 3.1 & $\mathrm{ND}$ & 5.8 & 4.1 & $\mathrm{ND}$ \\
\hline$C_{16: 0}$ & 3.7 & $\mathrm{ND}$ & 1.7 & $\mathrm{ND}$ & 3.5 \\
\hline iso- $\mathrm{C}_{13: 0} 3-\mathrm{OH}$ & 1.1 & $\mathrm{ND}$ & ND & ND & ND \\
\hline $\mathrm{C}_{18: 1} \omega 9 c$ & 1.3 & 13.8 & $\operatorname{tr}$ & ND & ND \\
\hline $\mathrm{C}_{18: 1} \omega 7 c$ & 1.2 & $\mathrm{ND}$ & ND & ND & $\mathrm{ND}$ \\
\hline iso- $\mathrm{C}_{13: 0}$ & $\operatorname{tr}$ & ND & 5.5 & 2.9 & ND \\
\hline iso- $\mathrm{C}_{17: 1} \omega 9 c$ & ND & ND & 15.0 & 1.1 & $\mathrm{ND}$ \\
\hline Summed feature $3 \dagger$ & 1.2 & $\mathrm{ND}$ & 5.9 & 1.0 & 22.2 \\
\hline Summed feature $4 \dagger$ & 13.0 & $\mathrm{ND}$ & ND & ND & 1.0 \\
\hline
\end{tabular}

${ }^{\star}$ C. andamanensis $\mathrm{AMV} 16^{\mathrm{T}}$ also contained $\mathrm{C}_{12: 0}(3.0 \%), \mathrm{C}_{13: 0}$ $(3.8 \%), \mathrm{C}_{14: 0}(3.0 \%)$, anteiso- $\mathrm{C}_{14: 0}(15.1 \%)$, anteiso- $\mathrm{C}_{15: 0}(4.6 \%)$, $\mathrm{C}_{15: 0}(28.7 \%), \mathrm{C}_{16: 1} \omega 9 c(23.9 \%)$ and $\mathrm{C}_{18: 1} \omega 9 c(13.8 \%)$, which are not listed in the table.

$\dagger$ Summed feature 3 comprised iso- $\mathrm{C}_{15: 0} 2-\mathrm{OH}$ and/or $\mathrm{C}_{16: 1} \omega 7 c$. Summed feature 4 comprised iso- $\mathrm{C}_{17: 1} \mathrm{I}$ and/or anteiso- $\mathrm{C}_{17: 1} \mathrm{~B}$.

Table 2. Differential characteristics between strain $311^{\top}$ and its phylogenetically closest relatives

Strains: 1, strain $311^{\mathrm{T}} ; 2$, C. andamanensis $\mathrm{AMV}^{\mathrm{T}}{ }^{\mathrm{T}}$ (data from Srinivas et al., 2011); 3, Marivirga tractuosa NBRC $15989^{\mathrm{T}}$ (data from this study unless indicated). ND, No data available.

\begin{tabular}{|lccc|}
\hline Characteristic & $\mathbf{1}$ & $\mathbf{2}$ & $\mathbf{3}$ \\
\hline Motility & + & - & + \\
Oxidase & - & + & + \\
Maximum growth temperature $\left({ }^{\circ} \mathrm{C}\right)$ & 37 & 37 & 40 \\
Nitrate reduction & + & + & - \\
Tolerance of $5 \% \mathrm{NaCl}$ & - & + & + \\
Enzyme activities & & & \\
$\quad$ Esterase & + & $\mathrm{ND}$ & - \\
$\quad$ Esterase lipase & + & + & - \\
$\quad N$-Acetyl- $\beta$-glucosaminidase & + & $\mathrm{ND}$ & - \\
$\quad \alpha$-Galactosidase & + & $\mathrm{ND}$ & - \\
$\quad \alpha$-Glucosidase & + & $\mathrm{ND}$ & - \\
$\quad$ Trypsin & - & $\mathrm{ND}$ & + \\
DNA G+C content $($ mol\%) & 47.1 & 50.9 & $36.1^{\star}$ \\
& & & \\
\hline
\end{tabular}

${ }^{\star}$ Data from Nedashkovskaya et al. (2010).

\section{Description of Cesiribacter roseus sp. nov.}

Cesiribacter roseus (ro'se.us. L. masc. adj. roseus rosecoloured, pink).

Cells are Gram-negative rods $(1.5-3 \times 0.4-0.5 \mu \mathrm{m})$ with an irregular fibril structure and are motile and strictly aerobic. Catalase-positive and oxidase-negative. Colonies are pink, circular and convex with regular margins. Flexirubin is detected. Growth occurs at $4-37{ }^{\circ} \mathrm{C}$ (optimum $30{ }^{\circ} \mathrm{C}$ ), at $\mathrm{pH}$ 7-10 (optimum $\mathrm{pH} 8$ ) and at $\mathrm{NaCl}$ concentrations of up to $3.0 \%$ (optimum $2.0 \%$ ). Positive for hydrolysis of aesculin, casein, starch and gelatin. In API ZYM tests, positive for alkaline phosphatase, esterase (C4), esterase lipase (C8), leucine arylamidase, valine arylamidase, naphthol-AS-BI-phosphohydrolase, $\alpha$-galactosidase, $N$ acetyl- $\beta$-glucosaminidase and $\alpha$-glucosidase, but negative for lipase (C14), cystine arylamidase, trypsin, $\alpha$-chymotrypsin, acid phosphatase, $\beta$-galactosidase, $\beta$-glucuronidase, $\beta$-glucosidase, $\alpha$-mannosidase and $\alpha$-fucosidase. In API 20NE test strips, positive reactions are observed for nitrate reduction, aesculin hydrolysis, gelatin hydrolysis and $\beta$-galactosidase (weak) and negative reactions are observed for arginine dihydrolase, indole production, urease and glucose fermentation. Does not assimilate Dglucose, L-arabinose, maltose, D-mannose, D-mannitol, $\mathrm{N}$-acetylglucosamine, adipic acid, capric acid, malic acid, potassium gluconate, trisodium citrate or phenylacetic acid. In API 20E tests, shows positive reactions for $\beta$ galactosidase (weak), tryptophan deaminase and gelatin hydrolysis, weakly positive reactions for oxidation of sucrose, melibiose, amygdalin and arabinose and negative reactions for arginine dihydrolase, lysine decarboxylase, ornithine decarboxylase, citrate utilization, $\mathrm{H}_{2} \mathrm{~S}$ production, Voges-Proskauer reaction, urease, indole production and oxidation of glucose, mannitol, inositol, sorbitol and rhamnose. Susceptible to (per disc) erythromycin (15 $\mu \mathrm{g}$ ), vancomycin $(30 \mu \mathrm{g})$, acheomycin $(30 \mu \mathrm{g})$ and penicillin (10 IU). The major quinone is MK-7. The DNA G+C content of the type strain is $47.1 \mathrm{~mol} \%$.

The type strain, $311^{\mathrm{T}}$ (=CCTCC AB $207142^{\mathrm{T}}=\mathrm{KACC}$ $\left.15456^{\mathrm{T}}\right)$, was isolated from desert sand in Xinjiang, China.

\section{Acknowledgements}

This work was supported by the R \& D Infrastructure and Facility Development Program from the Ministry of Science and Technology of the People's Republic of China (Grant203 no. 2005DKA21208).

\section{References}

Bernardet, J.-F., Nakagawa, Y. \& Holmes, B. (2002). Proposed minimal standards for describing new taxa of the family Flavobacteriaceae and emended description of the family. Int J Syst Evol Microbiol 52, 1049-1070.

Buczolits, S., Denner, E. B., Vybiral, D., Wieser, M., Kämpfer, P. \& Busse, H.-J. (2002). Classification of three airborne bacteria and proposal of Hymenobacter aerophilus sp. nov. Int J Syst Evol Microbiol 52, 445-456. 
Chun, J., Lee, J. H., Jung, Y., Kim, M., Kim, S., Kim, B. K. \& Lim, Y. W. (2007). EzTaxon: a web-based tool for the identification of prokaryotes based on $16 \mathrm{~S}$ ribosomal RNA gene sequences. Int J Syst Evol Microbiol 57, 2259-2261.

Felsenstein, J. (1985). Confidence limits on phylogenies: an approach using the bootstrap. Evolution 39, 783-791.

Gerhardt, P., Murray, R. G. E., Wood, W. A. \& Krieg, N. R. (1994) Methods for General and Molecular Bacteriology. Washington, DC: American Society for Microbiology.

Kimura, M. (1980). A simple method for estimating evolutionary rates of base substitutions through comparative studies of nucleotide sequences. J Mol Evol 16, 111-120.

Kumar, S., Tamura, K. \& Nei, M. (2004). MEGA3: integrated software for molecular evolutionary genetics analysis and sequence alignment. Brief Bioinform 5, 150-163.

Lau, S. C. K., Tsoi, M. M. Y., Li, X., Plakhotnikova, I., Dobretsov, S., Wu, M., Wong, P.-K., Pawlik, J. R. \& Qian, P.-Y. (2006). Description of Fabibacter halotolerans gen. nov., sp. nov. and Roseivirga spongicola sp. nov., and reclassification of [Marinicola] seohaensis as Roseivirga seohaensis comb. nov. Int J Syst Evol Microbiol 56, 1059-1065.

Mesbah, M., Premachandran, U. \& Whitman, W. B. (1989). Precise measurement of the $\mathrm{G}+\mathrm{C}$ content of deoxyribonucleic acid by highperformance liquid chromatography. Int J Syst Bacteriol 39, 159-167.

Nedashkovskaya, O. I., Kim, S. B., Lee, D. H., Lysenko, A. M., Shevchenko, L. S., Frolova, G. M., Mikhailov, V. V., Lee, K. H. \& Bae, K. S. (2005a). Roseivirga ehrenbergii gen. nov., sp. nov., a novel marine bacterium of the phylum 'Bacteroidetes', isolated from the green alga Ulva fenestrata. Int J Syst Evol Microbiol 55, 231-234.

Nedashkovskaya, O. I., Kim, S. B., Lysenko, A. M., Park, M. S., Mikhailov, V. V., Bae, K. S. \& Park, H. Y. (2005b). Roseivirga echinicomitans sp. nov., a novel marine bacterium isolated from the sea urchin Strongylocentrotus intermedius, and emended description of the genus Roseivirga. Int J Syst Evol Microbiol 55, 1797-1800.

Nedashkovskaya, O. I., Vancanneyt, M., Kim, S. B. \& Bae, K. S. (2010). Reclassification of Flexibacter tractuosus (Lewin 1969)
Leadbetter 1974 and 'Microscilla sericea' Lewin 1969 in the genus Marivirga gen. nov. as Marivirga tractuosa comb. nov. and Marivirga sericea nom. rev., comb. nov. Int J Syst Evol Microbiol 60, 1858-1863.

Rainey, F. A., Ward-Rainey, N., Kroppenstedt, R. M. \& Stackebrandt, E. (1996). The genus Nocardiopsis represents a phylogenetically coherent taxon and a distinct actinomycete lineage: proposal of Nocardiopsaceae fam. nov. Int J Syst Bacteriol 46, 1088-1092.

Saitou, N. \& Nei, M. (1987). The neighbor-joining method: a new method for reconstructing phylogenetic trees. Mol Biol Evol 4, 406425.

Seo, H.-S., Kwon, K. K., Yang, S.-H., Lee, H.-S., Bae, S. S., Lee, J.-H. \& Kim, S.-J. (2009). Marinoscillum gen. nov., a member of the family 'Flexibacteraceae', with Marinoscillum pacificum sp. nov. from a marine sponge and Marinoscillum furvescens nom. rev., comb. nov. Int J Syst Evol Microbiol 59, 1204-1208.

Srinivas, T. N. R., Anil Kumar, P., Madhu, S., Sunil, B., Sharma, T. V. R. S. \& Shivaji, S. (2011). Cesiribacter andamanensis gen. nov., sp. nov., isolated from a soil sample of a mud volcano. Int J Syst Evol Microbiol 61, 1521-1527.

Thompson, J. D., Gibson, T. J., Plewniak, F., Jeanmougin, F. \& Higgins, D. G. (1997). The CLUSTAL_X windows interface: flexible strategies for multiple sequence alignment aided by quality analysis tools. Nucleic Acids Res 25, 4876-4882.

Wilson, K. (1987). Preparation of genomic DNA from bacteria. In Current Protocols in Molecular Biology, pp. 2.4.1-2.4.2. Edited by F. M. Ausubel, R. Brent, R. E. Kingston, D. D. Moore, J. G. Seidman, J. A. Smith \& K. Struhl. New York: Wiley.

Xie, C. H. \& Yokota, A. (2003). Phylogenetic analyses of Lampropedia hyalina based on the 16S rRNA gene sequence. J Gen Appl Microbiol 49, 345-349.

Yoon, J., Adachi, K., Park, S., Kasai, H. \& Yokota, A. (2011). Aureibacter tunicatorum gen. nov., sp. nov., a marine bacterium isolated from a coral reef sea squirt, and description of Flammeovirgaceae fam. nov. Int J Syst Evol Microbiol 61, 2342-2347. 